Article

\title{
The Revaluation of Uninhabited Popular Patrimony under Environmental and Sustainability Parameters
}

\author{
Begoña Blandón ${ }^{1} * \mathbb{( D}$, Luís Palmero ${ }^{2}$ and Giacomo di Ruocco ${ }^{3(\mathbb{C}}$ \\ Architectural Construction Department 1, University of Seville, 41004 Sevilla, Spain \\ 2 Architectural Construction Department, University Politècnica of València, 46022 València, Spain; \\ lpalmero@csa.upv.es \\ 3 Departamento de Ingeniería Civil, Universitat degli Studi di Salerno, 84084 Fisciano, Italy; \\ gdiruocco@unisa.it \\ * Correspondence: bblandon@us.es
}

Received: 25 June 2020; Accepted: 10 July 2020; Published: 13 July 2020

\begin{abstract}
Abandoning rural areas requires promoting their repopulation. In Europe, wealth and life in these enclaves are valued. However, the current state of these houses does not meet actual needs and requires interventions to actualize current standards. Therefore, decisions in the design and execution of the works will generate a volume of construction and demolition waste (CDW), which must be managed sustainably out of respect towards its origin, the architecture, and the surrounding environment. This paper examines the prevention and management of CDW, providing control strategies and actions to monitor and plan them from the rehabilitation project itself. Some of the interventions carried out in recent years on this type of housing have been analyzed and the existing management protocols within the European Union have been reviewed, specifying their application in Mediterranean popular housing. As a result, we herein show a representative case that observes the existing reality regarding the destination of generated CDW and delves into their possibilities for use. We present these findings in order to reduce the energy cost resulting from manufacturing new materials and meeting the established sustainability and energy efficiency parameters.
\end{abstract}

Keywords: disinvestment; popular housing; rehabilitation works; sustainable construction; waste management; circular economy

\section{Introduction}

The year 2020 began by recognizing the end of an era. More specifically, this era was marked by important scientific and technological advances, such as the expansion of communications, interesting archaeological, astronomical, or biological findings that tackled challenges in medicine, biotechnology, or nanotechnology. Moreover, new discoveries supported technological progress in the information age. Likewise, this era made room for relevant decisions regarding greater social awareness on aspects as diverse as gender equality, quality of life for the elderly, or environmental deterioration and its consequences. However, the year 2020 will be remembered most for the international health and economic emergency caused by COVID-19. However, there may be an opportunity in which new habits with concern for the future of human health now take center stage. It is obvious that our social, labor, and habitat habits require reviewing (with environmental criteria), especially with regard to certain models of architecture, urban planning, environment, and city-life [1].

For years, the growth of large European cities has caused depopulation in rural areas. Although the origin of this important demographic imbalance is located in the middle of last century, when cities housed factories and needed abundant and unspecialized labor, these areas today still have the lowest population densities in the entire continent, and the rural exodus continues to grow. Likewise, in Asia, 
cities have grown exponentially in the face of attractive city living. Opportunities across the Asian continent are better compared to the isolated and resource-poor rural environments of Europe. As will be seen in many cases, perhaps life is not as hopeful as promised. As a novelty, during the pandemic, rural areas have been able to defend themselves during different stages of this pandemic and this favors possible future changes in population dynamics.

On the other hand, rural areas have a significant proportion of the population aged 65 years or older. The continued decline in birth rates and the increase in elderly life expectancy distorts the population pyramids. (Europe has $20 \%$ of its population above the age quoted and there is no generational replacement.) Italy, for example, has the highest median age in Europe [2]. Considering that in the next 50 years demographic forecasts will triple these figures, the level of depopulation to which these municipalities are subjected has not yet ceased and its consequences are aggravated [3].

With this concern, Spain can serve as an example of high depopulation [4]. As in other European Union countries like France or Italy, $40 \%$ of the municipalities are classified as having a severe risk of depopulation. The growth with which abandonment develops in these zones is one of the essential lines of study in order to enact possible solutions in the next decade [5]. In recent years, initiatives have emerged that seek to revitalize rural environments at the economic, demographic, and social level [6]. In 2017, Spain confronted the demographic challenge as state policy. Thus, in 2018, the 2018/2021 state housing plan [7] launched aid to rehabilitate housing for general interventions and promoted energy efficiency in rural areas, bringing its offer closer to young people and those aged over 65. In 2019, general guidelines were established as the 2030 Agenda and National Strategy, which constructed a plan to fight against depopulation in rural areas [8].

At present, administrations are implementing improvement policies in infrastructures and transport systems, betting on new lines and models of production and trade, defending sustainable agriculture and livestock, or rural tourism. Thus, technological advances are being considered that could make field work more efficient, present work alternatives in the case of an economic crisis, improve telecommunications (which have made telework possible during the period of coronavirus confinement), or, simply, the approach to a more natural life [9]. In the incoming decade, a new repopulation phenomenon is to be expected that, fueled by the wealth of these enclaves, demands the rural world as a habitat option. Now, the rural era will take center stage. The year 2020 is a decisive time to promote actions that slow down the isolation and review living conditions in these locations.

\section{Principles of Action and Objectives}

Residence rehousing options are divided between new work (i.e., visual alteration of the environment that surrounds them) and the occupation of existing and currently unoccupied homes (i.e., as a consequence of the abandonment process). However, the buildings available in these places do not respond to the needs of a new population, who will be forced to adapt buildings to the regulatory requirements and European guidelines on comfort, energy efficiency, and environmental sustainability. From an architectural point of view, the requirements that are demanded, at a typological, constructive, or technological level, are not considered in the original home [10]. Thus, any proposal will be accompanied by essential adaptation works (punctual or comprehensive) to achieve these objectives. In this regard, the environmental impact that the construction and demolition waste (CDW) generated deserves a study on the control of its production, the promotion of prevention, or any other recovery formula according to the current legislation.

In 2017, the construction industry consumed 36\% of the world's energy, which represents almost $40 \%$ of gas emissions and contributes to the current greenhouse effect and climate change. According to the Green Building Council (UKGBC) [11], more than 400 million tons of materials are used each year, $15 \%$ of fresh water and $25 \%$ of the world's wood. Annual global demand for sand and gravel is between 40 and 50 billion tons per year. On the other hand, construction produces a quarter of global waste with materials such as cement, metals, glass, or asphalt that end up in landfills or incinerators. This exorbitant expense is far from what is dealt with in international protocols. The term sustainable 
development (Brutland Report of the year 1978) is a concept that implies a very important change in the idea of guaranteeing an ecological attitude over time, within a framework that also emphasizes economic and social development. "Our Common Future" is the World Commission on Environment and Development's report that addresses such concerns (United Nations Headquarters, August 1987). In the years after the report was published, there were other world-renowned actions such as the famous Kyoto protocol, (Japan, December 11, 1997), whose March 2005 implementation led to an emission reduction of at least 5\% between 2008-2012, compared to emissions reported in 1990. This action and other subsequent ones highlight the global situation regarding gas emissions due to the release of polluting emissions into the atmosphere. The effects have manifested themselves through a progressive phenomenon of global warming, in addition to representing uncertainty about the residual availability of non-renewable resources, with all of the consequent potential environmental risks [12].

If this disproportionate level of consumption continues, the planet is headed for an energy and pollution crisis of irreparable consequences. The construction industry should be closely examined to prevent such consequences, given its material manufacturing waste propagation. The European Directive on Energy Efficiency [13] supports the revitalization of the market for the renovation of existing buildings: Member States must renovate at least 3\% of their building stock through rehabilitation and, if necessary, demolition and reconstruction. Likewise, to reach the goal of zero emissions before the end of the 21st century [14,15], all buildings, regardless of the country in which they are built, must produce not only the energy they consume but also the energy needed to build, maintain, and dismantle them via recycling their components.

Because existing rural homes lack attractive technical and comfortable conditions, we decided to study building intervention and observe the construction and demolition waste (CDW) impact on planned rehabilitation works. Thus, we propose the generated use of CDW, betting on recycling and/or reuse to incorporate materials and components back into buildings.

\section{Materials and Methods}

There is a clear antecedent to our work: to raise awareness for partly abandoned and depopulated heritages. Different seminars and congresses, such as the "Small Towns Conference" (STC-19) held in Salerno, Italy, emphasized the habitat situation that addresses sustainable strategies for the valorization of construction and the landscape/cultural/architectural heritage in inland areas [16]. Currently, the University of Seville's Higher Technical School of Architecture TEP 954-IN FACT (Investigation Factory) research group in coordination with professors from the Polytechnic University of Valencia's (Spain) Higher Technical School of Building Engineering and the Faculty of Engineering of the University of Salerno's, (Italy), are taking the opportunity to share and promote interventions that defend and protect the visual beauty of the rural environment.

In this work, we reviewed the European Union's existing management protocols, specifying their application in the example of popular architecture in the Mediterranean area. Our final task was to create actionable guidelines that guaranteed the sustainable quality of these interventions and to develop a monitoring guide that benefited the management and treatment of the indicated waste. This objective encompassed different stages differentiated into research phases according to their purpose and temporal state (Figure 1).

1. Phase 1: Studying risk locations. The scope of the intervention was specified by selecting locations of interest and going deeper into their architecture and recovery possibilities.

2. Phase 2: Producing CDW and studying the nature of CDW and its typology.

3. Phase 3: Managing CDW. Protocol for action in the rehabilitation of housing in small towns. After the data was collected, we analyzed the final destination of CDW in the cases studied.

4. Phase 4: Possibilities of taking advantage of the generated CDW. Reuse and study new recycled construction products. Currently, this work is still in the process of development. We continue to set new goals in this last phase. 


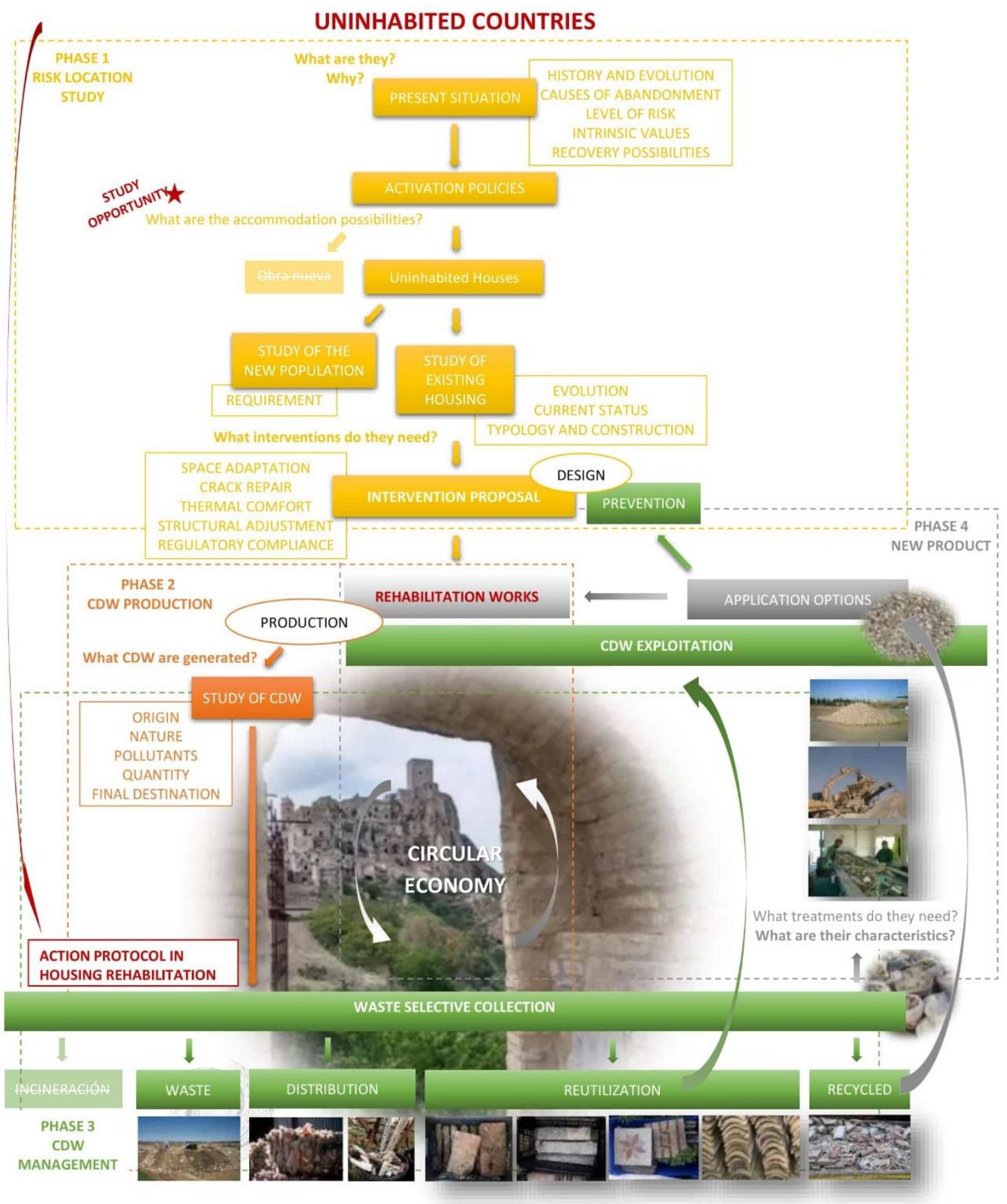

Figure 1. Outline of contents and defined stages in the research process.

\subsection{Study of the Municipalities and Identification of Affected Locations}

The history and evolution of rural area populations throughout the 20th century facilitates the understanding of what factors have led communities to their present situation. In the cases of warfare and agricultural production crises (i.e., labor force mitigation caused by the mechanization of working mediums), massive migrations can occur, which give rise to abandonment in many locations [17]. Young people flock to cities for job opportunities. Cities grew and benefited from the post-war baby boom, leaving rural areas forgotten. In the years 1960 to 1970, population growth in rural towns paralyzed, streets were empty, and inhabitants began aging and dying. In the 1990s, the abandonment dynamics to which many municipalities in the Mediterranean area are subjected to, led to alarming statistical data. 
To specify the scope of the intervention, different levels of risk were identified to locate the affected municipalities according to the number of inhabitants, causes of abandonment, context, and opportunity for recovery. The study was enriched with intrinsic values (i.e., landscape, culture, gastronomy, and architecture) and other parameters, such as an area's geography, economy, and current activation policies [18].

The scope of this study covers the following municipalities: Andalusia, Levante, and Catalonia (Spain); Occitania and the region of Provence-Alpes-Côte d'Azur (France); and Emilia-Romagna, Piedmont, Sicily, Tuscany, and Campania (Italy). All of these regions had less than 1000 inhabitants and highlighted the need for a recovery process. Currently, they have improvements in accesses, infrastructure, and services, so the need to provide a solution to the possible rehousing is immediate and requires a detailed study and an empty housing stock.

\subsection{Study of the Existing Housing}

In an area as extensive as the one proposed, architecture and construction vary as a consequence of geographical location, topography, climatology, and the various impacts incurred to these locations over centuries. This section identifies existing homes within the canons of vernacular architecture. We can deepen our knowledge of traditional architecture and thus learn to reactivate these areas by understanding construction valorization, landscapes, and cultural heritage [19].

Similar models have been observed in the Mediterranean area. Although the origin of some populations date back to prehistory and Roman times, the buildings examined in this study are largely from the 18th and 19th centuries. However, the poor evolution of the rural house verifies that there are no outstanding innovations and thus proves that surviving constructions steeped in history deserve consideration and respect [20]. In any of the analyzed cases, housing reflects rural life, as it is not far removed from the idea of comfort many people in the developed world have today [21]. Tradition and environment tend to justify the predominance of these functions in existing housing prototypes.

As a starting point, we examined each houses spaces and constructive solutions to determine their evolution and deficiencies. For data collection in the different locations, we developed a visit plan, which was not always successful. These visit plans have limited our inspection of the surrounding environment and architectural enclosures. To complete the study, the sample of dwellings was expanded to include homes with similar typological and construction characteristics (belonging to the same, or neighboring municipality). Although some of these were not abandoned, collecting data was more accessible.

In this study, three types of properties were observed according to their constructive typology, their walls, and their roof coverages and claddings, allowing for a first classification summarized in Figure 2. 


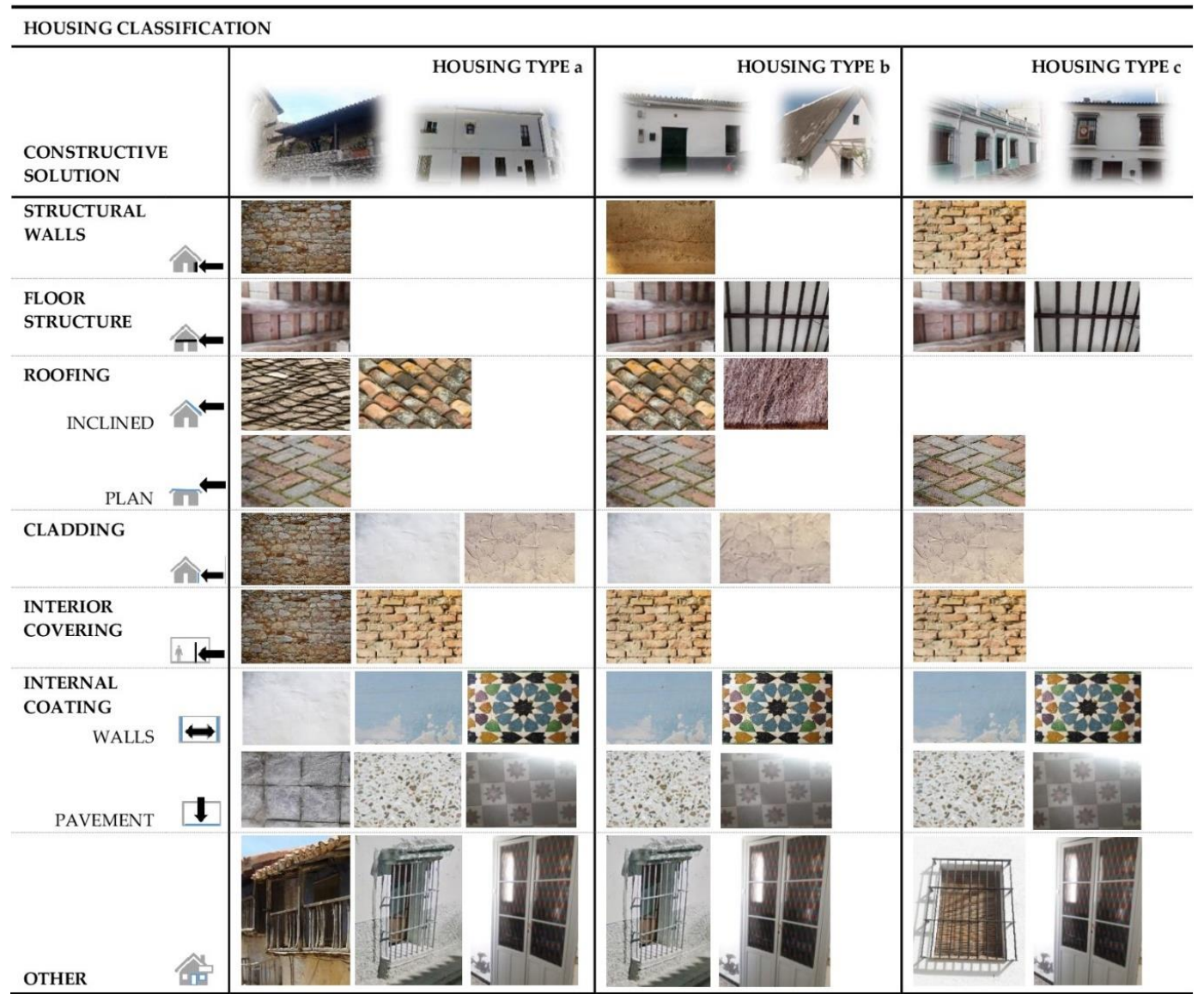

Figure 2. Typology of existing houses. Classification made according to the constructive solution and family of representative materials in each case.

\subsection{Proposed Interventions on Existing Housing}

The study of the original housing, its state of conservation, and the needs of new users, have confirmed the necessity of intervention. Since we did not use normative criterion (perhaps because these homes did not exist in their origins), the need for a formal study can hence be observed [22]. During the time period investigate in this study, the paradigm of environmental sustainability was hardly taken into account, which was an inevitable requirement when intervening in this type of construction. Knowledge of traditional architecture guided the search for sustainable strategies to guarantee respect for future interventions. We herein combined its technical adaptation and the value of the existing buildings.

From a construction point of view, the study of materials, products, techniques used, and plastic solutions allowed us to understand the evolution and responses over the years in comparison with their current state and nature of the CDW. Likewise, progressive location abandonment and their consequent lack of maintenance accelerated deterioration, causing defects and injuries that affected stability, habitability, and decoration. As can be extracted from Figure 3, the criteria followed in the Catalog of Constructive Rehabilitation Solutions [23] made it possible to decide which intervention was necessary. In this respect, the vertical supporting elements were scarce; thermal deficiencies detected in the surrounding elements of the property should be improved in $56 \%$ of the cases analyzed. However, solutions should be transferred and the original element was hardly affected). In $70 \%$ of houses, it was necessary to review the stability of the horizontal structure and roof. Moreover, it was necessary to guarantee the tightness of the roof in $68 \%$ of the cases. The intervention proposals included pavement revision and of interior patio conditioning in $76 \%$ of cases. When renovating the vertical cladding (interiors and exteriors), we needed to replace the carpentry and replace the majority 
of the facilities. The layout of the interior spaces and routes were affected by $50 \%$. In this regard, the intervention measures were grouped into three levels according to economic, technical, and social character and criteria [24]: basic level (i.e., elementary actions that affect installations and vertical finishes), medium level (i.e., redistribution of interior spaces, pavements, and thermal comfort), and intense level (i.e., action planned on structural elements, their renewal or reinforcement). In the required interventions, cleaning and sanitation of walls and leveling of floors were included.

\begin{tabular}{|c|c|c|c|c|c|c|c|c|c|c|c|c|c|c|}
\hline \multicolumn{15}{|c|}{ CURRENT CONDITION OF THE HOUSE } \\
\hline \multicolumn{3}{|l|}{ IDENTIFICATION } & \multicolumn{11}{|c|}{ INTERVENTION AREA } & \multirow{2}{*}{$\begin{array}{r}\text { INTERVENTION } \\
\text { LEVEL }\end{array}$} \\
\hline CODE & $\mathbf{N}^{o}$ & TYPE & Nit & $\hat{A}$ & $\mathrm{~N}^{4}$ & $\hat{n}=$ & $i \leftarrow$ & $\Leftrightarrow$ & 1 & -1 & 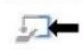 & $0^{\circ}$ & $\Rightarrow$ & \\
\hline ES ALROD 01 & 1 & $a+c$ & $\Delta$ & - & - & O & - & - & 0 & & O & 8 & $\bar{\Delta}$ & Strong \\
\hline ES BAVAL 01-02 & 2 & $\mathrm{~b}$ & & $\Delta$ & $\Delta$ & $\Delta$ & $\Delta$ & $\Delta$ & & $\Delta$ & - & - & $\Delta$ & Medium \\
\hline ES CAVEJ 01 & 1 & b & & - & & & & - & & & - & - & - & Strong \\
\hline ES CAVEJ $02-06^{\star}$ & 5 & a & & - & $\Delta$ & & & - & & & - & - & $\Delta$ & Strong \\
\hline ES COCAÑ 01 & 1 & a & & & P & & $\Delta$ & $\Delta$ & $\Delta$ & $\Delta$ & - & - & & Light \\
\hline ES COVIMI 01 & 1 & a & & $\Delta$ & - & $\Delta$ & $\Delta$ & P & $\Delta$ & & - & - & $\Delta$ & Medium \\
\hline ES GRAFER 01 & 1 & a & $\Delta$ & $\Delta$ & - & $\Delta$ & - & - & & - & - & - & & Strong \\
\hline ES HUGRA 01-03 & 3 & a & $\Delta$ & $\Delta$ & - & & & - & - & - & - & - & & Medium \\
\hline ES HUVAL 01 & 1 & a & & ○ & P & • & & $\Delta$ & $\Delta$ & ○ & - & - & & Medium \\
\hline ES MACAR 01-02 & 2 & c & & $\Delta$ & $\Delta$ & $\Delta$ & & $\Delta$ & & $\Delta$ & - & - & & Medium \\
\hline ES MAMAC 01 & 1 & a & $\Delta$ & $\Delta$ & $\Delta$ & - & $\Delta$ & - & O & & - & - & & Strong \\
\hline ES MUREV 01-02 & 2 & b & & & & O & & $\Delta$ & $\Delta$ & & - & - & & Light \\
\hline ES SEBUR 01-03 & 3 & c & & & & $\Delta$ & $\Delta$ & $\Delta$ & $\Delta$ & & $\Delta$ & $\Delta$ & & Light \\
\hline ES SECAS 01-03 & 3 & c & & & & $\Delta$ & $\Delta$ & $\Delta$ & $\Delta$ & $\Delta$ & P & - & $\Delta$ & Light \\
\hline ES SECAS 04-06 & 2 & $a+b$ & & & $\Delta$ & $\Delta$ & $\Delta$ & $\Delta$ & O & $\Delta$ & - & - & & Light \\
\hline ES SECON 01-02 & 2 & a & $\Delta$ & - & O & & & $\Delta$ & & ? & - & - & & Strong \\
\hline ES TACOR 01-04 & 4 & a & P & - & O & - & $\Delta$ & - & - & ○ & - & - & O & Strong \\
\hline ES TECAM 01 & 1 & a & $\Delta$ & - & P & & & - & - & - & - & O & & Strong \\
\hline ES ZABEL 01-04 & 4 & c & & & $\Delta$ & - & & - & O & & $\Delta$ & $\Delta$ & $\Delta$ & Light \\
\hline FR AIOZA 01 & 1 & c & & & & $\Delta$ & & $\Delta$ & $\Delta$ & $\Delta$ & $\Delta$ & $\Delta$ & & Light \\
\hline FR HECEL 01-02 & 2 & a & $\Delta$ & - & ○ & & & $\Delta$ & O & $\Delta$ & O & - & $\Delta$ & Strong \\
\hline FR PRCAN 01 & 1 & c & & & & $\Delta$ & & $\Delta$ & $\Delta$ & & $\Delta$ & $\Delta$ & & Light \\
\hline IT LUCOL 01-02 & 2 & a & $\Delta$ & $\Delta$ & O & - & - & O & ○ & $\Delta$ & - & - & & Medium \\
\hline IT PIBOR 02 & 2 & a & & & - & & & & & & $\Delta$ & - & $\Delta$ & Medium \\
\hline IT SIMES 01 & 1 & c & & & $\Delta$ & 0 & & - & $\Delta$ & & - & $\Delta$ & & Light \\
\hline IT SPPOR 01 & 1 & $a+b$ & P & - & & - & - & - & O & - & - & - & - & Strong \\
\hline IT SOVAM 01 & 1 & c & $\Delta$ & - & & - & & $\Delta$ & ○ & & - & O & - & Strong \\
\hline IT TOPIE 02 & 2 & a & & & $\Delta$ & & $\Delta$ & $\Delta$ & $\Delta$ & $\Delta$ & 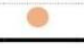 & O & & Light \\
\hline & & & & & & & & & & & & KELIH & OOD OF & INTERVENTION \\
\hline & & & & & & & & & & & $\bar{A}$ & LOV & $N$ LIKELY & Y INTERVENTION \\
\hline ES CAVEJ 03 & & LOCA & ZATIO & OF T & IE STU & DIED INT & IERVEN & NTION & & & - & & & Y INTERVENTION \\
\hline
\end{tabular}

Figure 3. Description of the original state of the houses and the character of the interventions. The reflected identification codes corresponded to the geographical location (country, province, or region and municipality of the locations). The type of dwelling $(a, b, c)$ is recognized from the classification shown in Figure 2. The selected dwelling will be the protagonist of the application and results described in Point 3.

In order to adapt the house to the required technical and comfort needs, the proposed interventions contemplated sustainable strategies that improved habitability, indoor air quality, and energy efficiency [25]. Passive thermal conditioning was sought whenever possible as an energy saving functionary. As part of prevention, the choice of materials and products with low environmental impact in their management was done to minimize CDW production [26].

\subsection{Construction and Demolition Waste Management Protocol CDW}

The CDW management protocol was drawn up on behalf of the European Commission as part of follow-up measures and served as a starting point in this study. This document is part of the 
Construction Strategy 2021 and the proposed measures will contribute to achieving the objective of the waste framework directive of recycling $70 \%$ of construction and demolition waste by 2020 . These results will thus close the life cycle of products by increasing recycling and reuse, and obtaining benefits for both the environment and the economy $[27,28]$.

By applying the CDW management protocol to different case studies, the conclusions and particularities detected allowed us to review its content and write a simplified action guide that files, orders, and classifies the CDW with the hope of rehabilitating houses in uninhabited towns. Tracking sheets were configured in a simple content format in which different sections related to the work data and description of the planned works favored the circular economy and the global competitiveness of the resulting products, i.e., CDW identification (origin and typology), CDW quantity estimation, the preventive measures to be adopted (to minimize the generation of CDW), the exploitation operations (on-site or its external management), and the final destination of the CDW surplus (specifying the place of discharge if necessary).

\section{Results: Application of the Protocol on Case Studies}

For the review of the CDW management protocol and its application, one of the representative cases when rehabilitating homes in southern Spain was typological; its construction characteristics made it representative in this study (see Appendix A: Figure A1). The house belonged to the municipality of Vejer de la Frontera, in the province of Cádiz (Spain). This municipality is part of the route of the White Towns in Andalusia and includes buildings defined by typical mountain locations. In this specific case, the position of the municipality gave it proximity and ease of access to the coast, which facilitated its activation in recent years. Today, it is part of the recovered villages moving away its prior status as an abandonment area. The planned interventions were developed mainly inside the house. We checked the stability of the horizontal structure, access to the rooftop, the renovation of vertical cladding and pavements (interiors), carpentry, and the facilities (see Appendix A: Figure A2). Considering waste management, the process allowed us to draw interesting conclusions about the intervention circumstances.

In compliance with RD 105/2008, the preparation of the waste management study during the drafting of the rehabilitation project [29] was carried out by a designer prior to the start of the work, which allowed us to check the veracity of the results and the greater or lesser success in the typology forecasts, quantity, and CDW destination. As part of this process, the adequacy of the prepared monitoring sheets was checked. We deduced deficiencies inherent in the data collection, such as the derived decisions and the incidents suffered during the execution of the work.

\subsection{Type and Characteristics of the Waste Generated}

In accordance with the European waste list [30], the study and identification of the generated waste allowed us to classify origin and place of production, stage of the process, danger, adhered contaminants, and alternatives in recovery [31]. As observed in the tracking sheets (see Appendix A: Figure A3), the planned CDW mostly came from the demolition/dismantling of existing elements in the original construction and, to a lesser extent, from the execution/replacement of the new proposed elements.

Figure 4 shows that the highest percentage of expected CDW was included in the inert group (a name that encompasses those products that do not cause environmental contamination over time). In total, $85 \%$ came from masonry, bricks, mortars, and other materials from the family of ceramics or stone. Within this percentage, ceramic waste (belonging to the elements of coverage, interior partitioning, and cladding) was found to have greater presence in the stony houses, even though it was a type of dwelling (type "a") with good supporting elements. Despite the initial classification made on the housing typology, the results obtained allowed us to unify the ceramic CDW in this type of construction. The CDW composition considered ceramic waste as a consequence of other materials and pastes with which it was in contact with. In the cases studied, the presence of lime, mortars, plasters, and paints attached to the pieces was inevitable. Although they occurred in a smaller proportion, 
they were considered as pollutants because they altered their original characteristics, quality, and posed a problem for new uses, i.e., plaster.

Figure 4 shows the important presence of wood as a consequence of the deterioration and rot of beams, demonstrating the need for new carpentry, glass, and metals/alloys. Unlike new construction, there were no remains from the demolition of concrete elements. Its only detection resulted from the removal of the compression layer from the original floors.

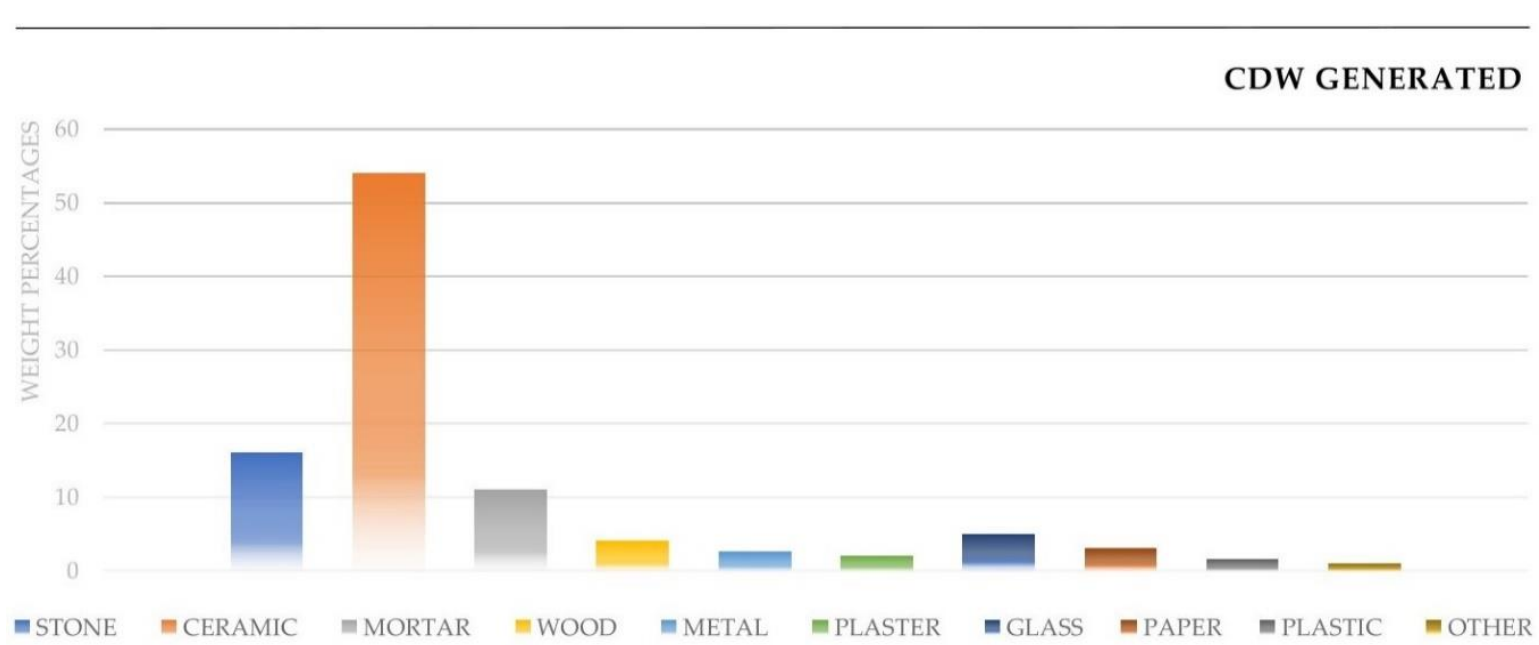

Figure 4. Proportion and nature of the generated construction and demolition waste (CDW). Coded housing application ESCAVEJ 03.

\subsection{Current Management of Generated CDW}

The final destination of the generated CDW in ESCAVEJ 03 (see Appendix A: Figure A4) was chosen as the only option for use. We made a first selection for waste, incorporating them almost immediately into the building. In this type of construction, due to its heritage value, the reuse of original materials/products turned out to be an inquiry demanded in many cases by the user himself, resorting to those materials and products whose state of conservation was worth incorporating. During the execution of this study, the lack of storage space made reuse impossible.

The CDW was initially considered as waste with no possibility of use. The final destination was the rubble dump in Chiclana de la Frontera $(32 \mathrm{~km})$. Given the volume and nature of the remaining $\mathrm{CDW}$, the review and management dynamics for the generated waste was considered unsuitable for direct reuse. It was necessary to study CDW characteristics for a possible assessment that allowed for the possibility of recycling.

\section{Discussion of Results and Progress on the Possibility of Recycling}

The information obtained in the set of case studies provides an interesting perspective when considering the management tools relevant to decision-making. In the cases studied, i.e., the ESCAVEJ 03 application, the reuse of original construction materials and products (e.g., ceramic tiles, old bricks, glazed tiles, clay tiles, stone tiles) was considered as the only option for use. The treatment and recycling of the generated CDW was not considered in any of the studied cases. Furthermore, as in other EU countries, rural communities are exposed to illegal CDW removal, controlled discharge points, and, sometimes, reduced CDW volume, inviting bad practices on roadsides, riverbanks, easily accessible farms, or abandoned lots [32]. Trying to avoid this practice, our research reviews final destinations and regulatory positions. In this regard, it is recommended to manage the future of inert CDW within the municipality itself (specifically within the intervention itself).

This study defends the on-site use of generated CDW, as it tries to incorporate CDW back into buildings, which extends its life cycle unlike anything else. To propose a reliable recycling option, it is 
necessary to consider it in advance of the rehabilitation project. Therefore, it is essential to specify the classification, separation, and on-site collection (selectively) of the generated CDW [33].

The nature and possible contaminants of the main house with which it was in contact allowed us to take a first approach to the existing waste properties that facilitates final decision-making. To do this, the study and characterization of a representative sample of granular material (MG) obtained after crushing the initially discarded CDW began. We sought simple and effective treatments that would allow them to be managed in on-site facilities. The MG obtained must be valued and, always consistent with the nature of the waste, it must reduce the current lack of confidence in the quality of the recycled materials. Logically, the costs derived from its management must also be added. Based on the characteristics obtained and, at a later stage, a new construction product obtained from recycling may be proposed. Figure 1 summarizes the full content of this investigation.

Although still in process, the laboratory of the Department of Architectural Construction I of the ETSA at the University of Seville is studying the characteristics of the planned MG according to the requirements and recommendations required to form the aggregates projected on coated pastes, whether vertical, graveled, or terrazzo pieces, for flooring and baseboards [34]. Obviously, given the nature of the materials and products that are part of the original construction systems, their low reliability is deduced and their use for other purposes is ruled out (such as aggregates a part of concrete or road sub-bases) [35].

In the case studied, the MG obtained presented a high percentage of hollow brick and tiles (from partitioning and cladding elements). In its larger pieces, this origin reflected a geometry of laminar aggregates with frequent edges that limited their use in construction. The shape coefficient and its index of flagstones and needles was reduced for sizes smaller than $4 \mathrm{~mm}$, which allowed the MG to be used as an for the proposed uses. In general, in other locations in the Mediterranean arch, with a greater presence of natural aggregates and/or solid brick, there was a higher percentage of rounded aggregates and the proportion of peaks and ridges was reduced, benefiting their final use for other uses. In any case, among its physical characteristics, the MG did not soften or decompose with water. Due to its ceramic nature, this value was innate to the selected material. Regarding their chemical characterization, the CDW selected for the sample contained a high percentage of clays (this result was expected during poor firing of old bricks and possible contamination of clay soils, sand, or gypsum, which, other than clays, were able to decompose and crumble during the test). Freezing was a quality offered by the studied MG for its resistance to chlorides or sulfates, which indicated its low aggressiveness towards metallic elements with which it could be in contact.

Based on the obtained results and future application of aggregate for terrazzo pavements, we can deduce that with correct selection and planning, the selected MG, after a cleaning process, would reduce the clay content and fines detected in its composition (Table 1). Likewise, the previous removal of the gypsum coatings influenced the results for certain coating solutions that were limited by the percentage of clays and light particles, which would confirm their suitability as MG. 
Table 1. Recycling possibilities of the granular material (MG) obtained after crushing the planned CDW. Application and evaluation as MG. Coded housing application ESCAVEJ 03.

\begin{tabular}{|c|c|c|c|c|}
\hline \multicolumn{5}{|c|}{ GRANULAR MATERIAL CHARACTERIZATION } \\
\hline \multicolumn{2}{|c|}{ REGULATORY REQUIREMENTS } & \multirow{2}{*}{$\begin{array}{l}\text { GRAVEL } \\
\text { Accepted }\end{array}$} & \multirow[t]{2}{*}{$\begin{array}{c}\text { SUBFLOOR } \\
\text { AGGREGATES }\end{array}$} & \multirow{2}{*}{$\begin{array}{c}\text { AGGREGATE } \\
\text { FOR FINISHING } \\
\text { Accepted }\end{array}$} \\
\hline $\begin{array}{l}\text { PARTICLE SIZE } \\
\text { COMPOSITION }\end{array}$ & TMA & & & \\
\hline \multirow{2}{*}{ GEOMETRY } & FORM & Accepted & & Accepted \\
\hline & $\begin{array}{c}\text { FRACTURE } \\
\text { FACES, UNEVEN, } \\
\text { SHARP EDGES, } \\
\text { ELONGATED }\end{array}$ & $\begin{array}{l}\text { Accepted with } \\
\text { diameter } \\
\text { limitations }\end{array}$ & & Accepted \\
\hline \multicolumn{2}{|c|}{ CONTENT THIN AGGREGATES } & Initially rejected & Initially rejected & Initially rejected \\
\hline \multicolumn{2}{|c|}{ WATER ABSORPTION } & & Accepted & \\
\hline \multicolumn{2}{|c|}{ LIGHTWEIGHT PARTICLES } & Accepted & & \\
\hline \multicolumn{2}{|c|}{ PLASTER CONTENT } & Initially rejected & Initially rejected & \\
\hline \multicolumn{2}{|c|}{ ORGANIC MATTER } & Accepted & Accepted & Accepted \\
\hline \multicolumn{2}{|c|}{ SOFT PARTICLES } & Accepted & & \\
\hline \multicolumn{2}{|c|}{ CLOTS OF CLAY } & Rejected & & \\
\hline \multicolumn{5}{|c|}{ JELIVITY } \\
\hline \multicolumn{2}{|c|}{ FIRE RESISTANCE } & Accepted & & \\
\hline \multicolumn{2}{|c|}{ CALCIUM OXIDE CONTENT } & & Accepted & Accepted \\
\hline \multicolumn{2}{|c|}{ LOSSES THROUGH CALCINATION } & & Accepted & Accepted \\
\hline \multicolumn{2}{|c|}{ SULPHUR COMPOUNDS } & Accepted & & \\
\hline \multicolumn{2}{|c|}{ RATING } & Accepted $^{1}$ & Accepted $^{1}$ & $\begin{array}{l}\text { Rejected for its } \\
\text { geometry }\end{array}$ \\
\hline
\end{tabular}

${ }^{1}$ Accepted by requiring excessive removal of finish and plaster.

Some of the obtained results could improve by recycling the MG obtained from CDW. Collections should be organized on-site on a selective basis, with protected storage, classification (labelling), origin, and CDW recoverability. Moreover, they must be located out of contact and access to the neighborhood to ensure the absence of organic waste from domestic rubbish. This prior selection would allow for the consideration of CDW organization, cleaning, and subsequent management. With regard to the manufacturing of terrazzo pieces, the product must be subjected to corresponding tests that guarantee its suitability for use in pedestrian traffic inside homes or patios. Moreover, it must have resistance to wear and tear, slipperiness, finish options, and textures, according to the envisaged area, insulation against impact noise, resistance to simple compression and flexotraction, resistance to certain chemical agents, etc.

It is well known that recycled products have to compete with traditional building materials. Thus, it is essential to achieve adequate levels of quality, a quality that derives directly from their origin and composition. If we consider these improvements as MG treatments, new results could be deduced to allow for betting on a new construction product that could be incorporated for building improvements, as reflected in Figure 5; Figure 6. 


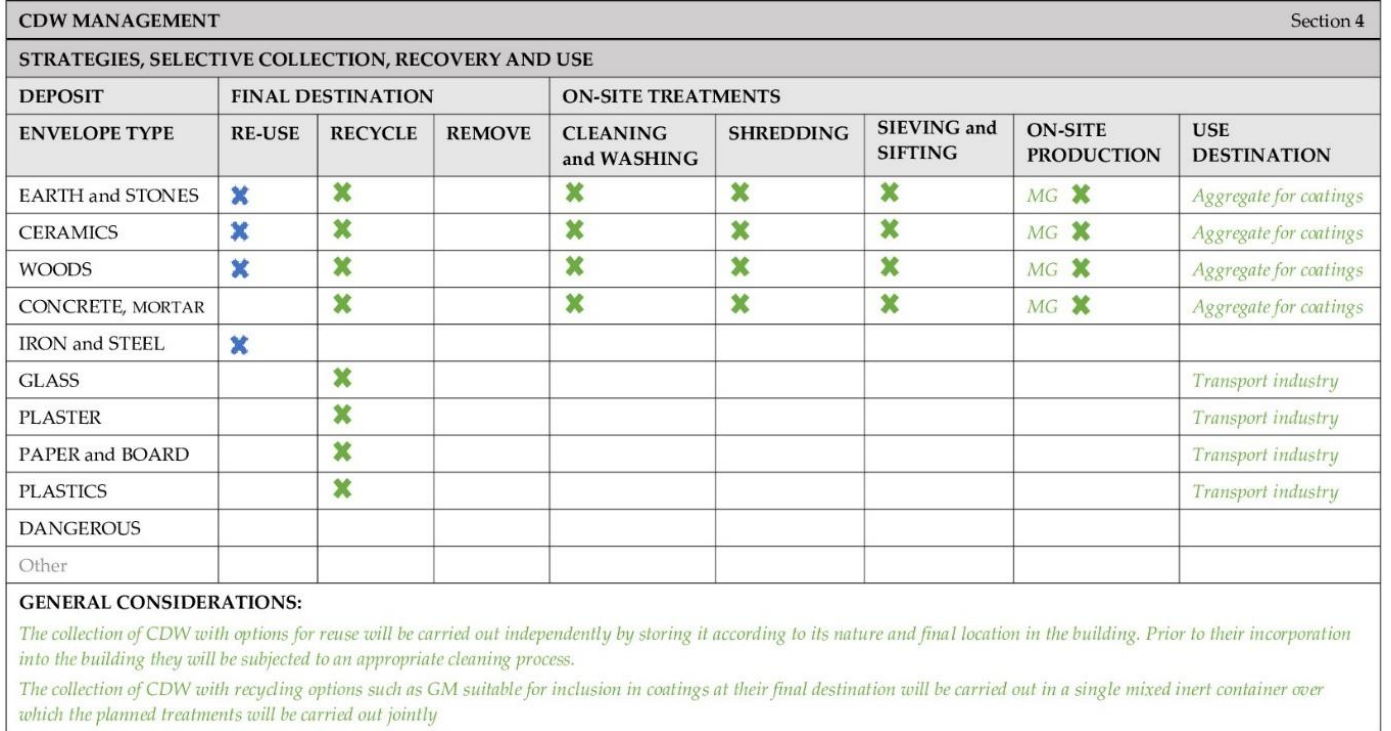

Figure 5. Tracking sheet. Proposal for the management of CDW generated on coded housing ESCAVEJ 03 (Section 4 on strategies for the use of generated CDW).

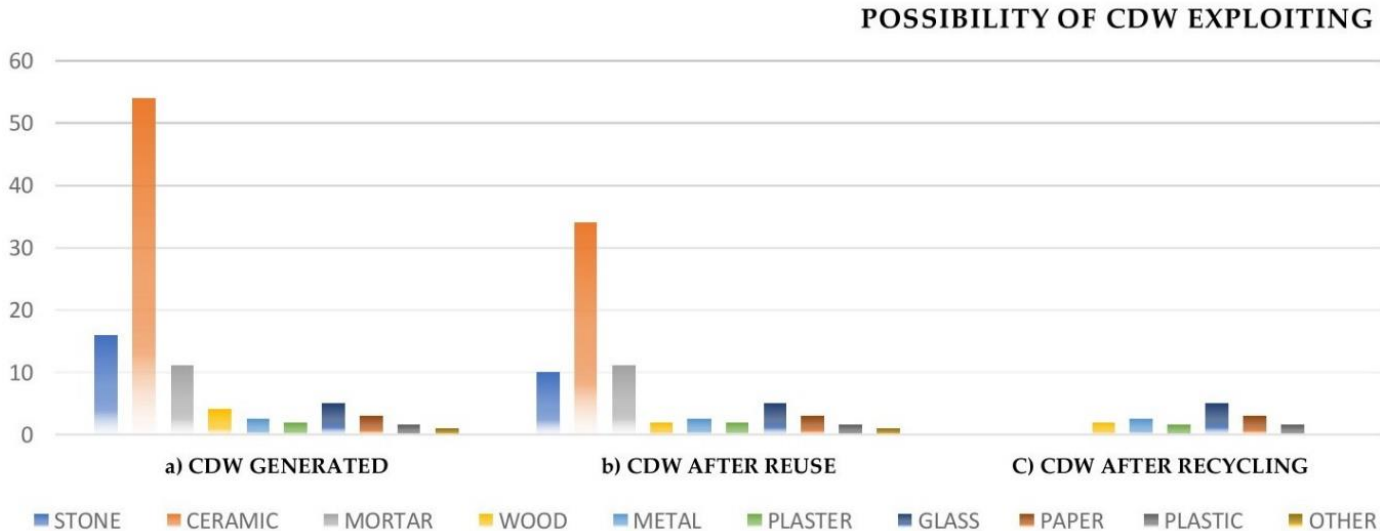

Figure 6. Results obtained after the planned use on-site for generated CDW. Comparison in the proportion and nature of the generated CDW: (a) surplus CDW (total); (b) surplus CDW after reuse; (c) surplus CDW after the management of reuse and recycling. Final result on CDW without the use option foreseen on-site. Coded housing application ESCAVEJ 03.

\section{Conclusions}

One of the great challenges of today is to better understand the vicissitudes of rural environments and building rehabilitations, specifically the prevention, reuse, and recycling of CDW in planned intervention works. The European Union's CDW protocol should be implemented in order to promote the specifications of data accumulation and decision-making surrounding housing recovery in uninhabited villages. Once we analyze our object of study, possibilities and advantages of this type of action were noted, especially for promoting a sustainable strategy beneficial to the environment (compared to new works, energy savings and environmental benefits are notable). With this type of intervention, we also pursued profitable economic and social sustainability.

Waste management provides a viable and guaranteed solution. Moreover, the historical regulatory framework represents unprecedented support. Many years have passed since the inception of Directive 91/156/CEE [36] and this process undoubtedly had a double environmental benefit. On the one hand, waste dumping should be avoided and on the other hand, the exploitation of natural resources, which in countries like Spain, has reached truly exaggerated levels, should be reduced. However, 
establishing an economy of rotation requires strategies specifying in recovery, recycling, and reuse, as well as timely assessments for agents in the process, whether they are of a legislative, technical, regulatory, or business nature.

Lastly, and in relation to the effective and convenient good building practice, "deconstruction" (i.e., demolition following the opposite process of construction) must be taken into account in order to demolish or selectively take down and make the most of a building's materials. In this work, we verified the process of acting on representative examples of popular architecture, which allowed us to adjust its content and structure while also guaranteeing its operation. In this respect, special emphasis was placed on identifying the origin and nature of waste, as well as the on-site measures and operations needed to minimize waste. Cumulatively, this provides sustainability benefits and a better quality of life, given the uniqueness of the housing types.

In recent years, the industry initially linked to the land has suffered a radical shift due to social changes, new materials, and new practices. Today, the capacity for pollution, contamination, energy expenditure, environmental deterioration, and resources scarcity is enormous. Therefore, it is necessary to consider new awareness programs aimed at minimizing and controlling waste. Thus, the "use" of popular architecture-which is often abandoned and in danger of becoming demolition waste-is becoming a first-rate alternative for achieving the maintenance and appreciation of architectural heritage. There is also an environmental benefit in the return of life to places with a privileged environment. This return of life offers a sense of authenticity, welfare, and positive future to its inhabitants

Author Contributions: B.B. conceived the original idea of the work; B.B. and L.P. they supervised the project and planned the applications; B.B., L.P. and G.d.R. developed the field work and interpreted the results; B.B. and L.P. wrote the manuscript. All authors have read and accepted the published version of the manuscript.

Funding: This research received no external funding.

Acknowledgments: The work developed would not have been possible without the collaboration of the Architect Jose Maria Ramos, for his knowledge and dedication to the rehabilitation of housing in the villages of Cadiz (Spain); For the data collection and study of abandoned houses, in different locations of the Mediterranean arch, we would like to thank the students from the Master in City and Sustainable Architecture MCAS, belonging to the course 2019/20 of the Superior Technical School of Architecture of the University of Seville, for their participation. The knowledge and characterization of CDW was possible thanks to the supervision of Reyes Rodriguez, who is the head of the Construction Laboratory for the School of Architecture at the University of Seville.

Conflicts of Interest: The authors declare no conflict of interest.

\section{Appendix A}

Tracking sheets. Action protocol. Coded housing application ESCAVEJ 03.

1. Figure A1: Follow-up sheet. Section 1: Identification and recognition of the original state.

2. Figure A2: Follow-up sheet. Section 2: Data collection of the intervention.

3. Figure A3: Follow-up sheet. Section 3: CDW forecast.

4. Figure A4: Follow-up sheet. Section 4: Strategies for the use of generated CDW.

Data corresponding to an example of application on a real case without considering recycling. 


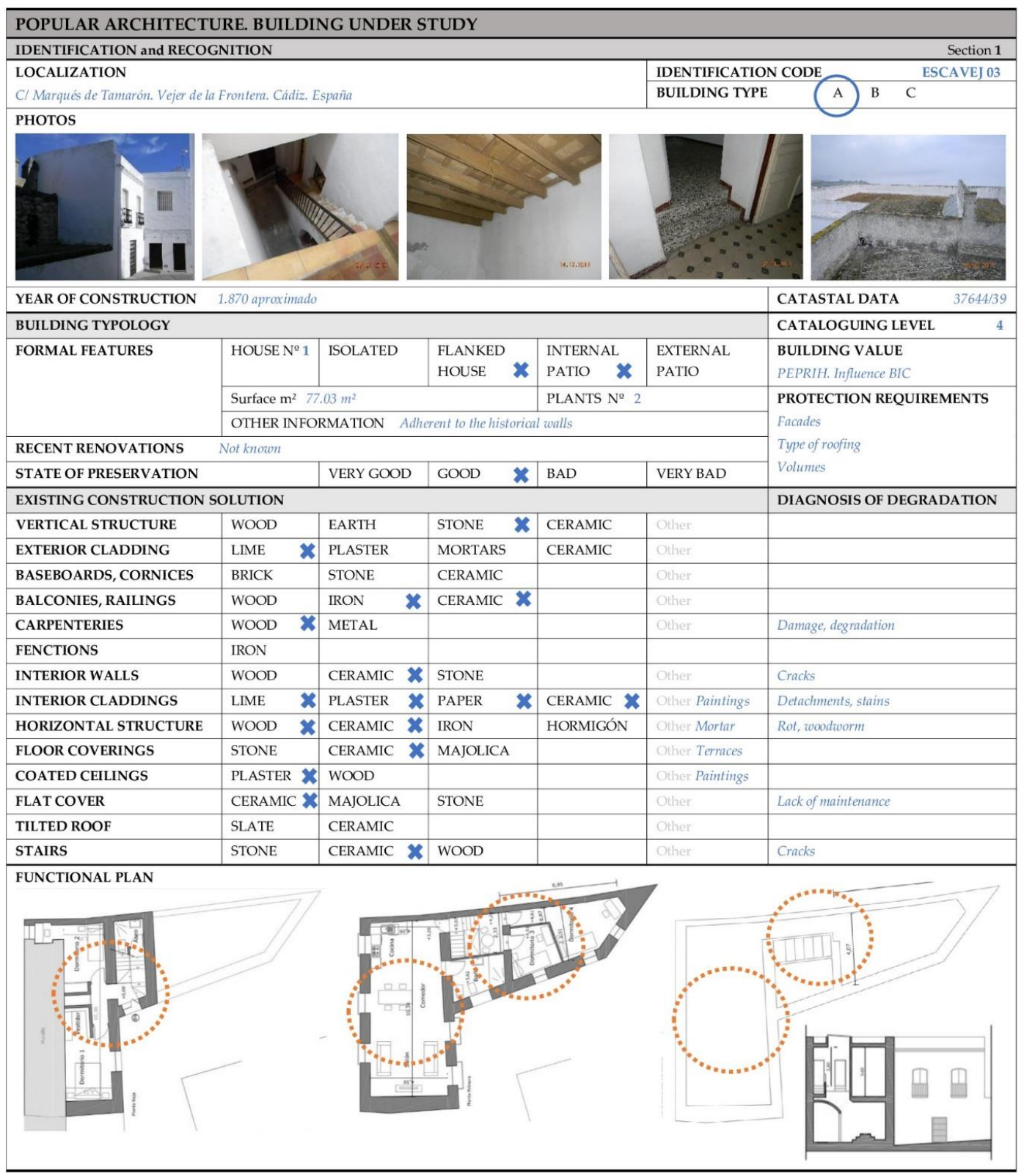

Figure A1. Follow-up sheet. Section 1: Identification and recognition of the original state.

\begin{tabular}{|c|c|c|c|c|c|c|}
\hline \multicolumn{7}{|c|}{$\begin{array}{l}\text { IMPLEMENTATION PROTOCOL FOR THE REHABILITATION OF ABANDONED COUNTRIES } \\
\text { INTERVENTION DATA }\end{array}$} \\
\hline \multicolumn{7}{|c|}{ AREA OF OPERATION } \\
\hline $\begin{array}{l}\text { EXTERNAL } \quad \boldsymbol{x} \\
\text { FACADES }\end{array}$ & ROOFING & $\begin{array}{l}\text { INTERNAL } \\
\text { ROOMS }\end{array}$ & $x$ & PATIO & $\begin{array}{l}\text { URBAN } \\
\text { CONTEXT }\end{array}$ & OTHER OUTBUILDINGS \\
\hline \multicolumn{7}{|c|}{ TYPE OF INTERVENTION } \\
\hline $\begin{array}{l}\text { WALLS' } \\
\text { STABILITY }\end{array}$ & $\begin{array}{l}\text { ENERGY } \\
\text { SAVING }\end{array}$ & $\begin{array}{l}\text { FLOOR } \\
\text { STABILITY }\end{array}$ & $\mathbf{x}$ & $\begin{array}{l}\text { ROOF } \\
\text { WATERPROOFING }\end{array}$ & $\begin{array}{l}\text { INSTALLATIONS } \\
\text { UPGRADING } \mathbf{x}\end{array}$ & $\begin{array}{l}\text { REDISTRIBUTION OF INTERNAL SPACES } \\
\text { On the first floor }\end{array}$ \\
\hline $\begin{array}{l}\text { KITCHEN } \\
\text { FURNISHING } \boldsymbol{x}\end{array}$ & $\begin{array}{l}\text { BATHROOM } \boldsymbol{x} \\
\text { FURNISHING }\end{array}$ & $\begin{array}{l}\text { VERTICAL } \\
\text { CLADDINGS }\end{array}$ & & $\begin{array}{l}\text { HORIZONTAL } \\
\text { COATING }\end{array}$ & INCLINED ROOF & $\begin{array}{l}\text { OTHER ACTIONS PLANNED } \\
\text { Roof access }\end{array}$ \\
\hline \multicolumn{6}{|c|}{ INTERVENTION LEVEL } & \multirow{2}{*}{$\begin{array}{l}\text { OBSERVATIONS } \\
\text { Interventions at the floors are localized }\end{array}$} \\
\hline DILAPIDATED BUI & ILDING & HEAVY & $\mathrm{x}$ & MEDIUM & LIGHT & \\
\hline
\end{tabular}

Figure A2. Follow-up sheet. Section 2: Data collection of the intervention. 


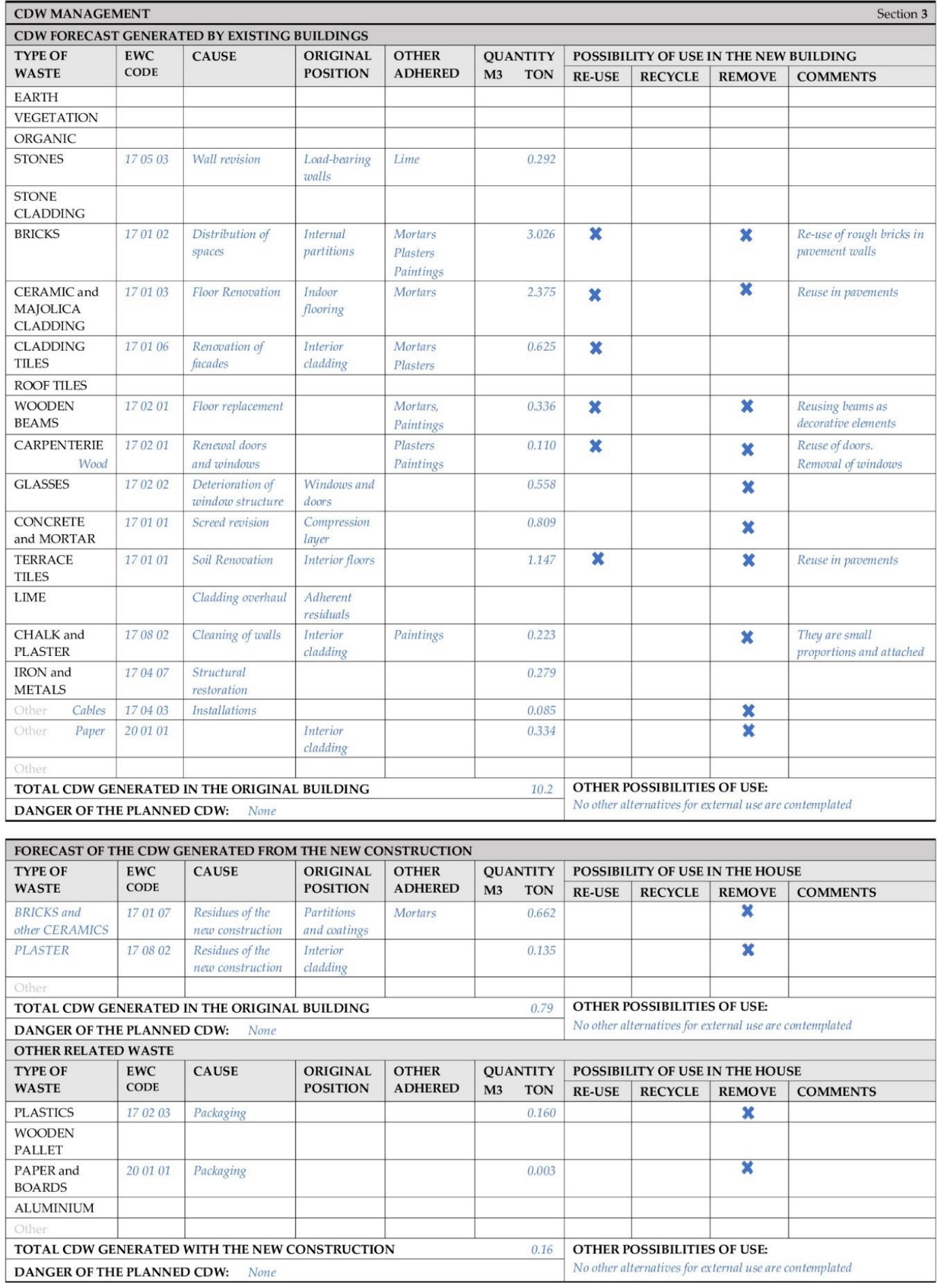

(Coming from the original housing and from the new intervention works)

Figure A3. Follow-up sheet. Section 3: CDW forecast. 


\begin{tabular}{|c|c|c|c|c|c|c|c|c|}
\hline \multicolumn{4}{|c|}{ CDW MANAGEMENT } & & & & & Section 4 \\
\hline \multicolumn{9}{|c|}{ STRATEGIES, SELECTIVE COLLECTION, RECOVERY AND USE } \\
\hline \multirow{2}{*}{$\begin{array}{l}\text { DEPOSIT } \\
\text { ENVELOPE } \\
\text { TYPE }\end{array}$} & \multicolumn{3}{|c|}{ FINAL DESTINATION } & \multicolumn{5}{|c|}{ ON-SITE TREATMENTS } \\
\hline & RE-USE & RECYCLE & REMOVE & $\begin{array}{l}\text { CLEANING } \\
\text { and WASHING }\end{array}$ & SHREDDING & $\begin{array}{l}\text { SIEVING and } \\
\text { SIFTING }\end{array}$ & $\begin{array}{l}\text { ON-SITE } \\
\text { PRODUCTION }\end{array}$ & USE DESTINATION \\
\hline \multicolumn{9}{|l|}{$\begin{array}{l}\text { EARTH and } \\
\text { STONES }\end{array}$} \\
\hline CERAMICS & $\mathbf{x}$ & & & & & & & External management \\
\hline WOODS & $\mathbf{x}$ & & & & & & & External management \\
\hline \multicolumn{9}{|l|}{$\begin{array}{l}\text { CONCRETE } \\
\text { and MORTAR }\end{array}$} \\
\hline \multicolumn{9}{|l|}{$\begin{array}{l}\text { IRON and } \\
\text { STEEL }\end{array}$} \\
\hline \multicolumn{9}{|l|}{ GLASS } \\
\hline \multicolumn{9}{|l|}{ PLASTER } \\
\hline \multicolumn{9}{|l|}{$\begin{array}{l}\text { PAPER and } \\
\text { BOARD }\end{array}$} \\
\hline \multicolumn{9}{|l|}{ PLASTICS } \\
\hline \multicolumn{9}{|l|}{ DANGEROUS } \\
\hline Other Mixed * & $\mathbf{x}$ & & $\mathbf{x}$ & & & & & External management \\
\hline \multicolumn{9}{|c|}{$\begin{array}{l}\text { GENERAL CONSIDERATIONS: } \\
\text { "Since the limit values established in RD 105/2008 are not exceeded, the CDWs are not separated on site. } \\
\text { The waste holder (contractor) or an external agent is responsible for separation, collection and transport for subsequent treatment in the plant (no separation on site due to lack of } \\
\text { physical space on the site). }\end{array}$} \\
\hline
\end{tabular}

Figure A4. Follow-up sheet. Section 4: Strategies for the use of generated CDW.

\section{References}

1. Ren, S.Y.; Gao, R.D.; Chen, Y.L. Fear can be more harmful than the severe acute respiratory syndrome coronavirus 2 in controlling the corona virus disease 2019 epidemic. World J. Clin. Cases 2019, 8, 652-857. [CrossRef] [PubMed]

2. Eurostat. Eurostad Stadistics Explained 2020; European Commission. Available online: https: //ec.europa.eu/eurostat/statistics-explained/index.php?title=Population_structure_and_ageing (accessed on 28 February 2020).

3. Circle. La Despoblación de las áreas Rurales. Circle J. Ecoembes 2019, 8. Available online: https://www. revistacircle.com/2019/02/22/la-despoblacion-de-las-zonas-rurales (accessed on 22 June 2019).

4. Atienza, J. Empty Spain Map and Southern Sparsely Populated Areas, SSPA. ETHIC J. 2019, 23. Available online: https://ethic.es/2019/04/el-mapa-de-la-espana-vacia (accessed on 12 September 2019).

5. Fiore, P.; Blandón, B.; D’Andria, E. Smart Villages for the Sustainable Regeneration of Small Municipalities. In Proceedings of the $3^{\circ}$ International Forum on Architecture and Urbanism, IFAU 2019, Tirana, Albania, 21 November 2019; Available online: https://fau.edu.al/home-1-2/ (accessed on 4 February 2020).

6. Moore, P. The Challenges Small Towns Face. In The Importance of Small Towns. The European Council for the Village and Small Town; ECOVAST, 2014; Cranbrook, England: by Stationery Express UK Ltd; Stationery Express Uk Ltd: Kent, UK, 2014; Available online: http://www.ecovast.org/papers/ECOVAST\% 20Importance\%20of\%20Small\%20towns.pdf (accessed on 1 June 2019).

7. Gobierno de España. Real Decreto 106/2018, de 9 de marzo, por el que se regula el Plan Estatal de Vivienda 2018-2021. Sección: I. Disposiciones generales; Publisher: Ministerio de Fomento. «BOE» núm. 61, de 10 de marzo de 2018; pp. 28868-28916. Ref. BOE-A-2018-3358. Available online: https: //www.boe.es/eli/es/rd/2018/03/09/106 (accessed on 15 December 2019).

8. Gobierno de España. Directrices Generales de la Estrategia Nacional Frente al Reto Demográfico; Ministerio de Política Territorial y Función Pública, Comisionado del Gobierno Frente al Reto Demográfico: Madrid, Spain, 2019; Available online: https://www.mptfp.gob.es/dam/es/portal/reto_demografico/Estrategia_Nacional/ directrices_generales_estrategia.pdf (accessed on 30 January 2020).

9. INE. Informe del Instituto Nacional de Estadística y Cartografía 2019; Consejería de Economía, Hacienda y Administraciones Públicas de la Junta de Andalucía: Andalucía, España, 2019; Available online: www. epdata.es (accessed on 20 February 2020).

10. Carrasco-Sáez, J.L.; Careaga Butter, M.; Badilla-Quintana, M.G. The New Pyramid of Needs for the Digital Citizen: A Transition towards Smart Human Cities. In Sustainable Smart Cities and Smart Villages Research. Sustain. J. 2018, 9, 2258. [CrossRef] 
11. Global Alliance for Buildings and Construction (GlobalABC). 2019 Global Status Report for Buildings and Construction. Towards a Zero-Emissions, Efficient and Resilient Buildings and Construction Sector; IEA, United Nations Environment Programme: Paris, France, 2019; ISBN 978-92-807-3768-4. Available online: https:// wedocs.unep.org/bitstream/handle/20.500.11822/30950/2019GSR.pdf?sequence=1\&isAllowed=y (accessed on 20 February 2020).

12. European Commission. A Roadmap for Moving to a Competitive Low-Carbon Economy in 2050; Communication from the Commission to The European Parliament, the Council, the European Economic and Social Committee and the Committee of the Region: Brussels, Belgium, 8 March 2011; Available online: https: //eur-lex.europa.eu/LexUriServ/LexUriServ.do?uri=COM:2011:0112:FIN:EN:PDF (accessed on 3 April 2020).

13. European Parliament and the Council of the European Union. Directive 2012/27/EC of the European Parliament and of the Council of 25 October 2012 on Energy Efficiency, Amending Directives 2009/125 / EC and 2010/30 / EU, and repealing the Directives 2004/8/CE y 2006/32/CE. Off. J. Eur. Commun. 2012. No. L 315/1. Available online: https://www.boe.es/doue/2012/315/L00001-00056.pdf (accessed on 15 March 2020).

14. Sicignano, E.; Di Ruocco, G.; Melella. Mitigation Strategies for Reduction of Embodied Energy and Carbon, in the Construction Systems of Contemporary Quality Architecture. Sustain. J. 2019, 11, 3806. [CrossRef]

15. Spenser, T.; Pierfederici, R.; Sartor, O.; Berghmans, N. State of the Low-Carbon Energy Union: Assessing the EU's Progress towards its 2030 and 2050 Climate Objectives; Study 2016, N 08/2016; Institut du développement durable et des relations internationals IDDRI: Paris, France; Available online: https://www.actu-environnement.com/ media/pdf/news-27832-rapport-iddri.pdf (accessed on 2 April 2020).

16. Fiore, P. Small Towns...From Problem to Resource. Rehabilitation of Abandoned Villages, Proceedings of the Abstracts Small Towns Conference, Fisciano, Italy, 19-20 September 2019; Fiore, P., D’Andria, E., Eds.; Coopetativa Universitaria Athena CUA: Salerno, Italy; ISBN 978-888944245-2-2. Available online: https://www.verderosa. it/wp-content/uploads/2019/09/STC2019_BOOK-OF-ABSTRACTS.pdf (accessed on 15 February 2020).

17. Instituto de Estadística de Andalucía (IEA), Junta de Andalucía. La transición demográfica hasta 1975. In Un siglo de demografía en Andalucía. La población desde 1900; Informes de la Junta de Andalucía: Andalucía, España, 2000; Available online: https://www.juntadeandalucia.es/institutodeestadisticaycartografia/sid/pub/ UnSigloDeDemografiaAnd.pdf (accessed on 1 September 2019).

18. Blandón, B.; Rodriguez, R. Recovering of Abandoned Towns. A Sustanaible Strategy for Construction and Demolition Waste Management. In I centri minori ... da problema a risorsa. Strategie sostenibili per la valorizzazione del patrimonio edilizio, paesaggistico e culturale nelle aree interne; Nuova Serie di Architettura FrancoAngeli; Plataforma FrancoAngeli: Milano, Italy, 2019; pp. 175-185. ISBN 978-8891798428. Available online: https://iris.unibs.it/retrieve/handle/11379/527112/112010/Passamani\%20I-Fasolini\%20S_Pasini\%20AGhidinelli\%20N_GAVARDO_STC\%202019.pdf (accessed on 10 May 2020).

19. Cillis, G.; Statuto, D.; Picuno, P. Vernacular Farm Buildings and Rural Landscape: A Geospatial Approach for Their Integrated Management. Sustain. J. 2020, 12, 4. [CrossRef]

20. Carrascosa, G.I. Caracterización constructiva de edificaciones vernáculas de carácter doméstico en Valverde de Burguillos: Catalogación, análisis, recomendaciones de mantenimiento y reparaciones en muros de tierra cruda y mampostería; Trabajo Fin de Grado; Departamento de Construcciones Arquitectónicas I, Universidad de Sevilla: Sevilla, Spain, 2018; Available online: https:/hdl.handle.net/11441/79494 (accessed on 10 September 2019).

21. Flores López, C. Arte y arquitectura en la vivienda española. Cap. III in La casa popular en España; Fomento de Construcciones y Contratas, S.A. D.L.: M-40308-1996. 1996, pp. 163-321. Available online: https://dialnet.unirioja.es/servlet/articulo?codigo=6738859 (accessed on 1 October 2019).

22. Gobierno de España. Real Decreto 314/2006, de 17 de marzo por el que se aprueba el Código Técnico de Edificación (CTE) en que establece las exigencias que deben cumplir los edificios en relación con los requisitos básicos de seguridad y habitabilidad establecidos en la Ley 38/1999 de 5 de noviembre de Ordenación de la Edificación LOE; Ministerio de Vivienda «BOE» núm. 74, de 28 de marzo de 2006 Ref. BOE-A-2006-5515. Available online: https://boe.es/buscar/pdf/2006/BOE-A-2006-5515-consolidado.pdf (accessed on 10 March 2020).

23. Instituto Valenciano de la Edificación. Catálogo de Soluciones Constructivas de Rehabilitación; 1st ed.; DRD 07/11; Consejería de Medio Ambiente, Agua, Urbanismo y Vivienda: Valencia, Spain, 2011; ISBN 978-84-96602-72-4. Available online: http://www.anerr.es/images/stories/pdf/catalogo-soluciones.pdf (accessed on 10 December 2019). 
24. Barrios Padura, A. Criterios de intervención de la rehabilitación arquitectónica y urbana para la promoción del envejecimiento active. In (Re)Programa. (Re)habilitación+(Re)generación+(Re)programación. El reciclaje y la gestión sostenible del parque edificado andaluz. Gestión de entornos habitables desde criterios de envejecimiento activo, género y habitabilidad urbana; Fondo Europeo de Desarrollo Regional, Consejería de Fomento y Vivienda, Junta de Andalucía: Andalucía, Españ, 2015; pp. 58-65. ISBN 9788460813825. Available online: https://dialnet.unirioja.es/servlet/libro?codigo=576336 (accessed on 15 December 2019).

25. Di Ruocco, G.; Melella, R. Evaluation of environmental sustainability threshold of "humid" and "dry" building systems, for reduction of embodied carbon $\left(\mathrm{CO}_{2}\right)$. Vitruvio. Int. J. Arch. Technol. Sustain. 2018, 3. [CrossRef]

26. Llatas Oliver, C.; Osmani, M. Development and validation of a building design waste reduction model. Waste Management. Int. J. Integr. Waste Manag. SCI. Technol. 2016, 56, 318-336. [CrossRef]

27. European Parliament and the Council of the European Union. Directive 2008/98/EC of the European Parliament and of the Council of 19 November 2008 on Waste and Repealing Certain Directives (Waste Framework Directive). Off. J. Eur. Commun. 2008. Available online: https://eur-lex.europa.eu/legal-content/ EN/TXT/?uri=celex\%3A32008L0098 (accessed on 20 February 2020).

28. European Commision. Protocolo de Gestión de Residuos de Construcción y Demolición en la UE. European Commisión and ECORYS. 2016. Ref. Ares (2016) 6914779 - 12/12/2016. Available online: http://aridosrecicladosdercd.es/wp-content/uploads/2018/06/ES-TRA-01.pdf (accessed on 1 October 2019).

29. Gobierno de España. Real Decreto 105/2008, de 1 de febrero, por el que se regula la producción y gestión de los residuos de construcción y demolición; Ministerio de la Presidencia «BOE» núm. 38, de 13 de febrero de 2008; Ref. BOE-A-2008-2486. Available online: https://www.boe.es/buscar/pdf/2008/BOE-A-2008-2486consolidado.pdf (accessed on 5 November 2019).

30. European Commision. European List of Waste (LER). Commission Decision of 18 December 2014 amending Decision 2000/532/EC on the list of waste pursuant to Directive 2008/98/EC of the European Parliament and of the Council. Official Journal of the European Communities 30.12.2014, No L 370/44. Available online: https: //eur-lex.europa.eu/legal-content/EN/TXT/?uri=CELEX\%3A32014D0955 (accessed on 20 February 2020).

31. Barroso Domínguez, V.M. Análisis de la Gestión de Residuos de Construcción y Demolición en la Comunidad Autónoma de Andalucía; Trabajo Fin de Carrera, Escuela Técnica Superior de Ingenieros, Universidad de Sevilla: Sevilla, Spain, 19 July 2013; Available online: http://bibing.us.es/proyectos/abreproy/30186/fichero/ Cap\%C3\%ADtulo+0.pdf (accessed on 2 April 2020).

32. Florín-Constantin, M. Construction and Demolition Waste in Romania: The Route from Illegal Dumping to Building Materials. Sustain. J. 2019, 11, 3179. Available online: https://www.mdpi.com/2071-1050/11/11/3179 (accessed on 15 January 2020).

33. Villoria Sáez, P.; Del Rio Merino, M.; Porras-Amores, C.; Astorqui, J.S.C.; Pericot, N.G. Analysis of Best Practices to Prevent and Manage the Waste Generated in Building Rehabilitation Works. Sustain. J. 2019, 11, 2796. [CrossRef]

34. Centro de Estudios y Experimentación de Obras Públicas (CEDEX), Ministerio de Fomento, Gobierno de España. In Catálogo de Residuos Utilizables en la Construcción; Ficha Técnica RCD actualizado, 2014; Monografías of Ministerio de Agricultura, Alimentación y Medio Ambiente; Dirección General de Calidad y Evaluación Ambiental: Madrid, España, 2007; p. 125. Available online: http://www.cedexmateriales.es/ (accessed on 15 April 2020).

35. Rolón Aguilar, J.; Blandón Gonzalez, B.; Huete Fuertes, R. Posibilidades de aplicación del material granular obtenido a partir de residuos de construcción y demolición de hormigón y cerámica. Res. J. 2005, 15, 32-36. Available online: https://dialnet.unirioja.es/servlet/articulo?codigo=1262253 (accessed on 3 March 2020).

36. Council of the European Communities. Directive 91/156/ EEC of 18 March 1991 amending Directive 75/442/EEC on waste. Off. J. Eur. Commun. 1991. No L 78/32. Available online: https://op.europa.eu/en/ publication-detail/-/publication/b2f0989d-59ec-426b-9ace-ef16e8494fc4/ (accessed on 15 May 2020).

(C) 2020 by the authors. Licensee MDPI, Basel, Switzerland. This article is an open access article distributed under the terms and conditions of the Creative Commons Attribution (CC BY) license (http://creativecommons.org/licenses/by/4.0/). 